\title{
ANALISIS KEBIJAKAN EFISIENSI BELANJA PEMERINTAH TERHADAP INDUSTRI AMENITAS SEBAGAI PENUNJANG PARIWISATA DI DKI JAKARTA
}

\section{Policy Analysis of Government Expenditure Efficiency on Industry Amenitas For Supporting Tourism in Jakarta}

\author{
Rostamaji Korniawan ${ }^{1}$ dan A. Dwi Siswanto
}

1Staff Biro Humas Kementerian Keuangan RI. Email : rostamaji_k@yahoo.com

2Staff Peneliti pada Badan Kebijakan Fiskal Kementerian Keuangan RI. Email : adsiswanto@yahoo.com

\begin{abstract}
This study would like to explain in the description of the efficiency of the government's fiscal policies are applied in conjunction with industry performance amenitas in DKI Jakarta Province. At the moment the Government prohibits civil servants doing activities with the use of hotel facilities, industrial amenitas give a negative reaction to that policy.The study shows that policies impact have not influence occupancy rate. It can be happened cause most the hotel guest come from domestic and foreign tourist not depent only from government demand.Therefore, in order to continue tospur industrial development amenitas, a major foothold should be directed to the tourism industry as a pillar of improving the performance of the industry. To improve the performance amenitas industry, improving the quality of human resources through the knowledge of community needs to be continuously improved in order to innovation and creativity they have developed can stimulate performance amenitas industry.
\end{abstract}

Keywords: Fiscal Efficiency, Amenitas Industry, and Tourism Industry

ABSTRAK

Kajian ini ingin menjelaskan secara deskripsi rencana kebijakan efisiensi fiskal pemerintah yang diterapkan dalam hubungannya dengan kinerja industri amenitas di Provinsi DKI Jakarta. Pada saat Pemerintah akan melarang pegawai negeri sipil melakukan kegiatan dengan menggunakan fasilitas hotel, industri amenitas memberikan reaksi negatif atas kebijakan tersebut. Hasil studi memperlihatkan bahwa tidak ada potensi dampak kebijakan yang mempengaruhi tingkat hunian. Hal ini bisa terjadi karena sebagian besar tamu hotel berasal dari tamu domestik dan asing bukan hanya bergantung pada permintaan pemerintah.Oleh karena itu, agar dapat terus memacu perkembangan industri amenitas, pijakan utama harus diarahkan pada industri pariwisata sebagai pilar meningkatkan kinerja industri tersebut. Untuk meningkatkan kinerja industri amenitas, peningkatan mutu sumber daya manusia melalui knowledge community perlu secara kontinyu ditingkatkan agar inovasi dan kreativitas yang mereka kembangkan dapat merangsang kinerja industri amenitas.

Kata kunci: Efisiensi Fiskal, Industri Amenitas, dan Industri Pariwisata

\section{PENDAHULUAN}

\section{Latar Belakang}

Sejak awal tahun 2014, tepatnya bulan Mei 2014, Presiden Susilo Bambang
Yudhoyono (SBY) telah mengeluarkan kebijakan penghematan anggaran. SBY mengeluarkan Instruksi Presiden Nomor 4 Tahun 2014 tentang Langkah-Langkah Penghematan dan Pemotongan Belanja 
Kementerian/Lembaga Dalam Rangka

Pelaksanaan Anggaran Pendapatan dan

Belanja Negara Tahun Anggaran 2014.

Penghematan ini juga menjadi wacana kandidat presiden Jokowi pada masa-masa kampanye. Menurut rencana, Pemerintahan di bawah kepemimpinan Joko Widodo dan Jusuf Kalla akan merevisi Anggaran Pendapatan dan Belanja Negara (APBN) Pemerintah apabila menang dalam Pemilihan Wakil Presiden (Pilpres). Skema perubahan yang dilakukan pemerintah adalah dengan melakukan efisiensi pengeluaran. Bentuk efisiensi tersebut adalah dengan mengurangi perjalanan dinas dan melarang rapat/kegiatan pegawai pemerintah diselenggarakan di Hotel. Kebijakan ini diambil dengan mempertimbangkan kurang memberikan dampak yang signifikan terhadap kesejahteraan rakyat. Pemangkasan anggaran bertujuan untuk melakukan penghematan. Hasil penghematan tersebut akan digunakan untuk membiayai pembangunan di sektor-sektor yang lebih produktif.

Penghematan dilakukan terutama terhadap belanja honorarium, perjalanan dinas, biaya rapat/konsinyering, iklan, pembangunan gedung kantor, pengadaan kendaaraan operasional, belanja bantuan sosial, sisa dana lelang atau swakelola serta anggaran dari kegiatan yang belum terikat kontrak.

Penghematan yang dilakukan dari sisi biaya rapat/konsinyering dalam bentuk pengurangan hingga larangan kegiatan di selenggarakan di luar kantor, termasuk di hotel-hotel berbintang. Akibat dari kebijakan ini maka timbul resistensi yang diperlihatkan oleh beberapa pihak. Salah satunya datang dari industri perhotelan (Amenitas). Kekhawatiran muncul dari dengan berkurangnya anggaran pemerintah tersebut, akan berimbas kepada omzet yang akan diterima oleh para pelaku usaha di industri amenitas. Terutama industri 104 amenitasyang hanya mengandalkan pemasukan dari pemerintah. Bagi mereka tentu akan memberikan pukulan yang mengejutkan akibat kebijakan yang dikeluarkan oleh pemerintah.

Hal itulah yang mendorong industri amenitasuntuk mengambil sikap resisten terhadap kebijakan pemerintahtersebut. Sementara itu di lain sisi, industri pariwisata merupakan sektor usaha yang mampu menyerap tenaga kerja dan menciptakan lapangan usaha lainnya merupakan pendukung beroperasinya aktivitas industri amenitas. Jika pemerintah mengeluarkan kebijakan larangan penggunaan hotel bagi pegawai negeri sipil, industri amenitas setidaknya bisa melihat potensi lainnya sebagai pengembang usaha yang mereka jalani.

Menurut Buhalis (2000), seperti yang ditulis oleh Maneenetr et.al (2014), amenitas merupakan salah satu dari enam kerangka yang diperlukan dalam destinas wisata yang ingin dituju oleh para wisatawan. Sedangkan destinasi sendiri diartikan Leiper (1995), masih dalam tulisan Maneenetr et.al (2014), sebagai tempat atau lokasi yang menjadi pilihan seseorang ketika melakukan perjalanan dan tinggal selama liburan untuk merasakan pengalaman tertentu. Dari pengertian tersebut terlihat bahwa seseorang memiliki kemungkinan untuk melakukan perjalanan wisata ke suatu tempat dan membutuhkan penginapan (hotel).

\section{Perumusan masalah}

Pariwisata merupakan salah satu sektor yang berkontribusi positif terhadap pertumbuhan dan perkembangan industri amenitas. Melihat adanya hubungan yang positif tersebut, kajian ini secara spesifik merumuskan masalah "bagaimana efektifitas kebijakan melarang Pegawai Negeri Sipil (PNS) menggunakan hotel sebagai tempat kegiatan terhadap perkembangan industri amenitas?”

\section{Tujuan}

Secara umum, kajian ini memiliki tujuan menggambarkan keadaan pariwisata yang ada di provinsi DKI Jakarta dalam kaitannya dengan adanya kebijakan baru 
pemerintah. Sedangkan tujuan spesifiknya adalah :

1. Mengidentifikasi perubahan-perubahan jumlah tamu akibat dari kebijakan larangan menggunakan fasilitas hotel untuk kegiatan PNS.

2. Merancang rekomendasi alternatif kebijakan mengatasi dampak negatif yang muncul dari penerapkan kebijakan larangan tersebut terhadap industri amenitas di DKI Jakarta.

\section{METODE PENELITIAN}

Kebijakan larangan untuk meningkatkan efisiensi belanja pemerintah guna lebih memperbesar alokasi anggaran belanja di sektor-sektor produktif, terutama infrastruktur, mendapat reaksi negatif dari pengelola bisnis perhotelan. Untuk itu dilakukan analisis guna mengetahui efektifitas dari kebijakan tersebut dalam kaitannya dengan perkembangan industri perhotelan tersebut. Efektifitas atau tidaknya kebijakan tersebut dilihat dari sisi ada tidaknya perubahan-perubahanakibat dari kebijakan tersebut, khususnya terhadap jumlah tamu Indonesia pada hotel bintang di Jakarta paska diberlakukannya kebijakan larangan tersebut.

Metode analisis data yang digunakan dalam kajian ini antara lain metode deskriptif dan metode kualitatif. Metode deskriptif digunakan untuk mengetahui reaksi-reaksi atas kebijakan tersebut dan perubahan-perubahan yang terjadi. Sedangkan metode kualitatif antara lain berupa analisis perkembangan sebelum dan sesudah kebijakan tersebut dikeluarkan pemerintah, terutama jumlah tamu pada hotel berbintang yang ada di DKI Jakarta.

\section{HASIL DAN PEMBAHASAN}

\section{Profile Tamu Sebelum Kebijakan}

Presiden SBY telah berkali-kali mengeluarkan kebijakan penghematan selama era pemerintahannya. Tujuan dari penghematan sebagai upaya meningkatkan ruang fiskal pemerintah. Dengan semakin luasnya ruang fiskal, maka tersedia alokasi belanja untuk infrastruktur. Pemerintah sejak awal telah mencanangkan pentingnya alokasi belanja bagi infrastruktur. Pemerintah merencanakan untuk mengalokasikan lebih banyak belanja untuk pengeluaran infrastruktur dibandingkan alokasi belanja bagi keperluan lain. Termasuk belanja pertemuan-pertemuan dan rapat-rapat yang selama ini diselenggarakan di luar kantor (di hotel). Pada awal masa pemerintahan yang baru ini, belanja untuk kegiatan rapat dan kegiatan sejenisnya di luar kantor, khususnya di hotel, dilarang untuk dilakukan.

Dampak dari kebijakan ini menimbulkan kekhawatiran di sejumlah kalangan pengusaha perhotelan dan restoran. Pada sisi lain, Propinsi DKI Jakarta sebagai ibukota negara, merupakan tempat kantor-kantor pemerintah pusat dan pemerintah daerah yang memiliki jumlah hotel dan restoran terbesar di Indonesia. Keberadaan hotel tersebut disamping memberikan manfaat bagi sektor pariwisata, juga memberikan dukungan bagi penyelenggaraan kegiatan pelayanan pemerintahan. Disamping itu, di DKI Jakarta, terdapat kantor-kantor pemerintah pusat dan daerah yang relatif cukup banyak telah mempengaruhi aktivitas di berbagai bidang. Belanja pemerintah pusat dan daerah di Jakarta relatif cukup besar. Terdapat 34 kementerian dan 28 lembaga pemerintah non kementerian yang berada di Jakarta. Total pegawai pada kementerian dan lembaga pemerintah non kementerian lebih dari 200 ribu orang. Pegawai Pemda DKI sendiri mencapai sekitar 70 ribu orang. ${ }^{1}$

${ }^{1}$ Pemprov Jakarta Dukung Rencana Moratorium CPNS. Sumber : Kantor Berita Antara. 3 Nopember 2014. 
Tabel 1. Tingkat Penghunian Kamar pada Hotel Bintang di Provinsi DKI Jakarta 2014

\begin{tabular}{|c|c|c|c|c|c|c|c|c|c|}
\hline Propinsi & Januari & Februari & Maret & April & Mei & Juni & Juli & Agustus & September \\
\hline DKI & 53.55 & 54.67 & 57.32 & 59.28 & 59.62 & 60.41 & 56.72 & 56.75 & 58.91 \\
\hline
\end{tabular}

Sumber: BPS DKI Jakarta - Diolah.

Sebagaimana ditampilkan dalam tabel 1, tingkat hunian memiliki kecenderungan terus mengalami pertumbuhan. Selama tahun 2014, tingkat hunian tertinggi terjadi pada bulan Juni, yaitu sebesar 60,41 persen. Tingginya tingkat hunian pada bulan Juni 2014 merupakan akibat dari adanya liburan semester pertama yang dilakukan oleh para pelajar dan mahasiswa. Bulan Juni merupakan masa libur yang cukup panjang. Sehingga tingkat hunian yang tinggi memang disebabkan karena adanya libur panjang sekolah. Pada bulan-bulan selanjutnya, tingkat hunian mengalami penurunan yang relatif cukup besar. Terutama pada bulan Juli dan Agustus. Kembali meningkat pada September dan Oktober. Peningkatan ini bisa bisa diduga karena adanya aktivitas lain di luar sektor pariwisata yang menggunakan fasilitas hotel untuk menyelenggarakan kegiatan.

\section{Profile Tamu Setelah Kebijakan}

Kebijakan larangan menggunakan fasilitas hotel sebagaimana tertuang dalam Peraturan tersebut berlaku mulai tanggal 1 Desember 2014. Implikasi dari kebijakan tersebut dapat dilihat dari realisasi tamu Indonesia yang menginap di Hotel berbintang di DKI Jakarta. Dibandingkan dengan tahun lalu pada bulan yang sama, terlihat bahwa tidak terjadi penurunan ratarata lama menginap. Ini menandakan bahwa kebijakan tersebut secara langsung maupun tidak langsung belum mempengaruhi bisnis perhotelan.

Tabel 2. Rata-Rata Lama Menginap Tamu Indonesia Hotel Berbintang di DKI Jakarta Menurut Klasifikasi Hotel, Bulan November 2013, Agustus dan September 2014 (Hari).

\begin{tabular}{llllllc}
\hline \multicolumn{1}{c}{ Bulan } & 1 & 2 & 3 & 4 & 5 & Gabungan \\
\hline September 2013 & 1,64 & 1,60 & 1,67 & 1,81 & 1,77 & 1,72 \\
Agustus 2014 & 1,53 & 1,61 & 1,78 & 2,21 & 2,06 & 1,91 \\
September 2014 & 1,29 & 1,68 & 1,79 & 2,08 & 2,19 & 1,88 \\
\hline
\end{tabular}

Sumber: BPS DKI Jakarta - diolah.

Dengan demikian, perlu dilakukan pengamatan yang lebih panjang terkait dampak dari Surat Edaran tersebut. Sehingga data pada bulan Desember dimana kebijakan tersebut mulai dilaksanakan, belum secara keseluruhan memberikan informasi yang cukup. Apalagi pada bulan Desember 2014, pada 2 minggu terakhir merupakan musim liburan dan menjelang Natal - Tahun Baru. Adanya kedua peristiwa tersebut bisa jadi menjadi salah satu faktor yang menyebabkan tetap tingginya lama menginap tamu.
Jika dibandingkan dengan Tabel 3, terlihat bahwa hotel berbintang di Jakarta sangat mengandalkan tamu domestik. Terlihat dari rendahnya rasio tamu asing terhadap tamu Indonesia. Sebagai contoh, rasio tamu asing total selama Nopember 2014 hanya sebesar 0,25. Artinya 75 persen tamu hotel berasal dari tamu Indonesia bukan tamu asing. Dengan kata lain hotel di Jakarta mengandalkan pemasukan yang bersumber dari tamu domestik. 
Tabel 3. RasioTamu Asing Terhadap Tamu Indonesia Untuk Hotel Berbintang di DKI Jakarta Bulan September 2013, Agustus dan September 2014

\begin{tabular}{ccccccc}
\hline \multirow{2}{*}{ Bulan/Tahun } & \multicolumn{5}{c}{ Bintang } & \multirow{2}{*}{ Gabungan } \\
\cline { 2 - 6 } & 1 & 2 & 3 & 4 & 5 & 0,25 \\
September 2013 & 0,02 & 0,11 & 0,09 & 0,16 & 0,85 & 0,25 \\
Agustus 2014 & 0,03 & 0,06 & 0,11 & 0,22 & 0,75 & 0,20 \\
September 2014 & 0,01 & 0,05 & 0,18 & 0,18 & 0,51 & 0,518 \\
\hline
\end{tabular}

Sumber: BPS - Diolah.

\section{Pariwisatadi Provinsi DKI Jakarta}

Provinsi DKI Jakarta menjadi pusatperkembangan berbagai macam industri yang bergerak di sektor jasa. Dengan pendapatan regional bruto yang mencapai 1.256 triliun rupiah di tahun 2013, DKI Jakarta menjadi provinsi yang memiliki penghasilan paling tinggi bila dibandingkan dengan provinsi lainnya di Indonesia. Tingginya nilai pendapatan regional bruto tersebut lebih banyak ditopang oleh siklus pertumbuhan usaha sektor jasa, khususnya industri finansial. Dalam perkembangannya, kota Jakarta mengalami pasang surut seiring dengan pergantian kepala daerah yang memimpin provinsi ini. Permasalahan yang dialami provinsi ini pun semakin kompleks dan berkembang. Permasalahan yang paling menonjol adalah permasalahan sosial dan pengelolaan tata ruang kota yang membutuhkan waktu yang cukup lama untuk menjadikannnya kota yang ideal. Sejak tahun 2012, DKI Jakarta dipimpin oleh Gubernur Joko Widodo, masyarakat berharap segala permasalahan di DKI Jakarta dapat segera diselesaikan. Namun pemerintahan Gubernur Joko Widodo tampaknya belum memberikan perubahan yang terlalu signifikan, terutama permasalahan utama yang dialami kota ini, yaitu kemacetan dan banjir. Dalam analisanya, Steinberg (2007) juga mengidentifikasikan kemacetan dan banjir sebagai bagian dari permasalahan yang dialami oleh kota Jakarta, selain permasalahan perumahan, lingkungan, polusi, dan bencana.

Meskipun DKI Jakarta memiliki ragam permasalahan, DKI Jakarta tetap memiliki karakteristik dan daya tarik tersendiri yang dapat digunakan sebagai nilai jual yang layak untuk pengembangan kota ini kedepannya. Keragaman etnis yang mendiami kota Jakarta merupakan salah satu daya tarik yang dimiliki kota ini sebagai ikon yang unik yang mendukung tumbuh dan berkembangnya sektor pariwisata di provinsi DKI Jakarta.Setiap tahun, perkembangan pariwisata di DKI Jakarta terus diupayakan dan di pantau oleh pemerintahan daerah setempat. Upaya pelestarian sektor pariwisata menjadi perhatian pemerintah daerah setempat agar usaha yang mendukung tumbuh dan berkembangnya sektor pariwisata juga dapat dikembangkan secara bersama-sama.

Industri amenitas termasuk salah satu sektor jasa yang turut mendukung berkembangnya industri pariwisata di DKI Jakarta. Selain itu,keberadaan Usaha Mikro, Kecil, dan Menengah (UMKM) juga menjadi sektor ekonomi rakyat yang turut mengambil manfaat atas kehadiran industri pariwisata di DKI Jakarta. Sektosektor usaha tersebut memiliki kontribusi yang positif dalam menunjang pertumbuhan ekonomi regional.

Melihat pentingnya pariwisata bagi pertumbuhan ekonomi regional, pemerintah daerah DKI Jakarta terus memperbaiki strategi, pola, dan pelayanan yang diperlukan untuk menggairahkan mobilitas industri pariwisatanya. Menurut Sunaryo (2013, hal.106), DKI Jakarta tengah mengupayakan improvisasi pada lokasi yang dianggap strategis agar bisa menarik sejumlah wisatawan untuk datang berkunjung ke kota Jakarta. Lokasi tersebut antara lain kawasan Kepulauan Seribu, kawasan Kota Tua, kawasan Cbd Jakarta Kota, dan kawasan Cibubur-Taman Mini Indonesia Indah (TMII).Kawasan 
kepulauan seribu merupakan kawasan yang memiliki obyek wisata natural yang dapat memberikan kenyamanan bagi para wisatawan yang datang dengan tujuan untuk melihat kekayaan alam yang di miliki kota Jakarta. Kawasan pulau seribu memiliki ragam obyek wisata natural.

Ciri khas yang dapat terlihat dari obyek wisata natural yang dapat ditemui di kawasan pulau seribu adalah pantai. Kawasan pantai tersebut dapat dijumpai di beberapa tempat, seperti pulau Tidung, pulau Harapan, pulau Pari, pulau Pramuka, pulau Ayer, pulau Pelangi, pulau Sepa, pulau Putri, pulau Kotok, pulau Pantara, dan pulau Bidadari ${ }^{2}$. Ciri khas yang serupa antara satu pulau dengan pulau yang lain menyiratkan bahwa para wisatawan memiliki opsi untuk menentukan lokasi mana yang ingin mereka kunjungi.

Selain obyek wisata natural, kota Jakarta juga menawarkan obyek wisata artifisial yang dapat dijumpai dalam bentuk bangunan bersejarah, museum maupun wahana yang ditujukan untuk mencari kesenangan dan hiburan seperti wahana dunia fantasi. Obyek-obyek wisata ini semuanya merupakan wujud dari obyek wisata artifisial, meskipun ada juga obyek wisata yang tampaknya natural namun obyek wisata tersebut merupakan kreasi hasil ciptaan manusia, seperti Taman Mini Indonesia Indah (TMII).

Secara historis, keberadaan seluruhjenis obyek wisata tersebut sudah lama terbentuk. Sebagian masyarakat sudah menganggap keberadaan obyek wisata tersebut sebagai hal yang biasabiasa saja. Untuk terus memberikan rangsangan dan motivasi kepada masyarakat nasional maupun internasional untuk tetap berkunjung ke obyek wisata yang adai di kota Jakarta, sejumlah pelaku usaha yang berkecimpung di dunia pariwisata melakukan beberapa terobosan melalui gagasan kreatif dan karya inovasi mereka. Gagasan kreatif dan karya inovatif mereka pada dasarnya merupakan bagian

${ }^{2}$ pulauseributraveling.com dari ekonomi kreatif yang merangsang usaha mandiri di dalam pergerakan ekonomi kerakyatan. Ekonomi kreatif akan memicu kebebasan masyarakat untuk menciptakan komoditas dan gagasan yang berbeda dengan yang sebelumnya. Bahkan, dengan kreativitas, komoditas dan gagasan yang dihasilkan bisa memiliki nilai tambah karena keunikannya. Sebagai contoh, beberapa paket wisata pernah ditawarkan oleh beberapa kelompok orang. Paket wisata yang mereka tawarkan sangat tidak lazim.

Paket-paket wisata tersebut antara lain seperti tour wisata untuk melihat kampung-kampung kumuh yang ada di sekitar Jakarta, tour wisata mengunjungi tempat-tempat yang angker, ataupun tour wisata untuk melihat kehidupan anak-anak malam yang ada di Jakarta. Wisata tersebut memang terkesan aneh dan sangat jarang terlihat maupun terdengar, namun keberadaannya memiliki pangsa pasar tersendiri bagi para wisatawan yang telah mengetahuinya sehingga wisatawan tidak segan-segan memberikan nilai lebih sebagai nilai tambah bagi obyek wisata yang berbeda tersebut.

Kreativitas tour wisata diatas merupakan bagian dari ekonomi wisata kreatif yang ditawarkan oleh pelaku usaha di dalam industri pariwisata di kota Jakarta. Masih banyak kreativitas usaha yang dilakukan oleh para pelaku usaha yang bergerak di dalam industri pariwisata tersebut. Dengan melakukan koordinasi dengan beberapa sektor usaha lainnya, termasuk pemerintah, pelaku usaha di industri pariwisata berusaha untuk mengembangkan usahanya agar industri ini dapat bertahan. Pemerintah daerah DKI jakarta tampaknya sejalan dengan para pelaku usaha di industri pariwisata tersebut yang ingin melakukan ekspansi usahanya.

Sejalan dengan upaya pemerintah untuk mendorong pelaku usaha menjalankan usahanya yang mandiri, keberadaan industri amenitas yang menjadi sektor penopang kelangsungan industri pariwisata akan menjadi indikator 
keberhasilan usaha pemerintah yang telah mendorong kemandirian ekonomi riil untuk berinovasi. Dengan kebijakan efisiensi fiskal oleh pemerintah yang kontroversial yang melarang pegawai negeri sipil melakukan kegiatannya di hotel, industri amenitas diuji untuk dapat melihat situasi yang berkembang saat ini sehingga hal ini dapat menjadi indikator apakah mereka mampu menangkap peluang yang ada atau sebaliknya. Pada sub bahasan berikutnya, paparan kebutuhan industri amenitas akan terlihat melalui mobilitas kegiatan yang terjadi disektor pariwisata.

\section{Pariwisata Bagi Kebutuhan Industri Amenitas}

Faslitas penginapan merupakan kebutuhan yang diperlukan para wisatawan ketika berkunjung ke suatu wilayah atau negara. Kota Jakarta yang menjadi salah satu tujuan para wisatawan juga memiliki fasilitas penginapan. Secara umum, konektivitas pertumbuhan industri pariwisata terhadap industri amenitas akan memberikan korelasi yang positif jika kedua pertumbuhan industri tersebut samasama menghasilkan pertumbuhan yang positif. Korelasi pertumbuhan positif dimaksud memiliki arti bahwapara pelaku usaha industri amenitas akan menambah jumlah supply fasilitas yang mereka berikan untuk keuntungan para wisatawan jika perkembangan sektor pariwisata menunjukkan indikasi peningkatan yang cukup signifikan. Tabel 4 di bawah ingin menujukkan korelasi yang terjadi antara pertumbuhan jumlah kunjungan wisatawan dengan pertumbuhan jumlah hotel yang di bangun di kota Jakarta.

Tabel 5. Tingkat Hunian Hotel

\begin{tabular}{lrrrr}
\hline & \multicolumn{2}{c}{2009} & \multicolumn{2}{c}{2010} \\
\hline Tamu Asing & Bintang & Non Bintang & Bintang & Non Bintang \\
Tamu Indonesia & 654.200 & 12.404 & 882.900 & 11.932 \\
Total & 3.556 .600 & 1.365 .376 & 3.932 .400 & 1.112 .064 \\
Total Bintang + Non Bintang & 4.207 .800 & 1.377 .780 & 4.815 .300 & 1.123 .996 \\
\hline
\end{tabular}

Tabel 4. Jumlah Hotel dan Kedatangan

Wisatawan Mancanegara

\begin{tabular}{lrr}
\hline \multicolumn{2}{c}{2009} & 2010 \\
\hline $\begin{array}{l}\text { Pembangunan Hotel di Jakarta } \\
\text { Jenis Hotel }\end{array}$ & \\
\hline Hotel Melati & 141 & 147 \\
Hotel Berbintang & 153 & 165 \\
$\quad$ Total & 294 & 312
\end{tabular}

Kedatangan Wisatawan Asing di Jakarta

Pintu Kedatangan

\begin{tabular}{crr}
\hline Soekarno Hatta & 1.930 .440 & 1.823 .636 \\
Tanjung Priok & 59.212 & 63.859 \\
\cline { 2 - 3 } Total & 1.449 .654 & 1.887 .495 \\
\hline
\end{tabular}

Sumber: Kementerian Pariwisata - Biro Pusat Statistik, diolah.

Data statistik Kementerian Pariwisata yang ada di dalam Tabel 4 memperlihatkan peningkatan jumlah kunjungan wisatawan mancanegera yang datang ke provinsi DKI Jakarta, baik melalui pintu bandara Soekarno Hatta maupun pintu masuk pelabuhan Tanjung Priok. Tahun 2009 jumlah wisatawan mancanegara yang datang ke kota Jakarta melalui kedua pintu sebanyak 1.449.652 wisatawan. Jumlah tersebut meningkat di tahun 2010 hingga mencapai 1.887.495 wisatawan.

Sementara itu, data Biro Pusat Statistik (BPS) wilayah DKI Jakarta yang ada di dalam Tabel 4 juga memperlihatkan peningkatan jumlah pembangunan hotel yang ada di kota Jakarta. Baik hotel kelas melati maupun hotel kelas berbintang, jumlah hotel mengalami sedikit peningkatan antara tahun 2009 dan 2010. Tahun 2009, jumlah hotel melati dan hotel kelas berbintang berjumlah sebanyak 294 hotel. Kemudian pada tahun 2010, jumlah tersebut meningkat sebanyak 18 hotel, sehingga jika di total,jumlah kedua jenis hotel itu menjadi sebanyak 312 hotel.

Sumber: BPS - diolah. 
Pertumbuhan pembangunan hotel yang ada di Jakarta diimbangi dengan pertambahan tingkat hunian hotel. Tabel 5 menggambarkan kondisi peningkatan tingkat hunian selama dua tahun, yaitu tahun 2009 dan tahun 2010. Peningkatan tingkat hunian hotel mengindikasikan bahwa pertumbuhan industri amenitas yang meningkat akibat bertambahnya jumlah kunjungan wisatawan juga diimbangi dengan peningkatan tingkat hunian hotel. Secara rinci Tabel 5 menjelaskan bahwa tahun 2009, jumlah tamu mancanegara dan Indonesia yang menginap di hotel yang berbintang maupun non berbintang berjumlah kurang lebih 5.585.580 penginap. Sedangkan tahun 2010, jumlah tamu mancanegara dan Indonesia yang menginap di hotel yang berbintang maupun non bintang sebanyak kurang lebih 5.939.296 penginap. Peningkatan jumlah tamu yang menginap di kedua jenis hotel tersebut memperlihatkan bahwa industri amenitas memiliki prospek yang menarik baik untuk kalangan profesional pengusaha maupun untuk para konsumen yang ingin mencari sensasi kenyamanan tinggal di dalam hotel.Peningkatan pertumbuhan jumlah hotel yang dibangun di kota Jakarta tersebut juga secara implisit memberitahukan kepada para pelaku usaha bahwa persaingan usaha tampaknya akan semakin kompetitif. Jika kompetisi semakin meningkat, berbagai macam cara dilakukan para pelaku usaha untuk menarik jumlah pengunjung untuk menggunakan fasilitas hotel, seperti penurunan tarif agar pengunjung tertarik untuk menginap.

Namun di tengah-tengah peningkatan pertumbuhan pembangunan hotel, industri amenitas harus dihadapkan dengan tantangan baru di mana kebijakan efisiensi fiskal yang dilakukan pemerintah terhadap larangan penggunaan hotel dalam kegiatan yang diselenggarakan pegawai negeri sipil telah menjadi polemik di kalangan industri amenitas yang ada. Larangan tersebut tentu akan berdampak kepada kinerja industri amenitas di mana sisi pendapatan akan semakin berkurang. Melihat kebijakan tersebut, beragam tanggapan akhirnya muncul untuk menyikapi kebijakan yang dianggap kurang berpihak kepada industri amenitas.

Salah satu tanggapan datang dari Perhimpunan Hotel dan Restoran Indonesia (PHRI) cabang Jawa Timur. Mereka menilai kebijakan pemerintah yang melarang pegawai negeri sipil melakukan kegiatan resminya di dalam hotel akan berdampak kepada penurunan omzet yang mereka terima. Analisa mereka menyebutkan bahwa penurunan pendapatan bisa terjadi antara 20 sampai dengan 50 persen. Untuk hotel yang berbintang, penurunan pendapatan mungkin bisa terjadi antara 30-50 persen. Sedangkan untuk hotel yang non berbintang, penurunan pendapatan mungkin terjadi sekitar 20-30 persen ${ }^{3}$.

Selain itu, PHRI cabang Jawa Timur juga menyebutkan bahwa kontribusi wisatawan yang berkunjung ke daerah Jawa Timur hanya berkisar kurang lebih 350 ribu wisatawan. Jumlah kunjungan wisatawan tersebut tidak terlalu signifikan untuk menopang pertumbuhan dan perkembangan industri amenitas di Jawa Timur. Dengan penurunan pendapatan yang bersumber dari anggaran pemerintah, industri amenitas akan semakin terpuruk terlebih industri pariwisata yang ada di provinsi Jawa Timur belum memberikan manfaat yang optimal bagi perkembangan industri mereka.

Sikap resistensi yang diperlihatkan oleh perhimpunan hotel dan restoran Indonesia tersebut dibalikan dengan fakta yang memperlihatkan kontribusi industri amenitas kepada negara. Di satu sisi, amenitas di provinsi Jawa Timur dapat memberikan pendapatan pemerintah daerah sebanyak kurang lebih 400 miliar rupiah. Sementara itu di lain sisi, PHRI pusat menyatakan bahwa industri amenitas nasional mampu menyumbangkan pajak untuk sektor hotel dan restoran sekitar 50

${ }^{3}$ Tempo.co, 8 November 2014 
triliun rupiah pertahunnya ${ }^{4}$. Dari perhitungan pendapatan pajak hotel dan restoran tersebut, Provinsi DKI Jakarta dan Bali merupakan provinsi yang memberikan kontribusi terbesar untuk pendapatan pajak restoran dan hotel.

Data dukungan dan informasi tentang kontribusi industri amenitas terhadap negara melalui pendapatan pajak hotel dan restoran tersebut menjadi alasan mengapa industri amenitas bersikap resisten terhadap kebijakan pemerintah tentang larangan penggunaan hotel bagi pegawai negeri sipil. Jika demikian adanya, fakta ini memperlihatkan bahwa industri amenitas memiliki ketergantungan yang besar terhadap anggaran pemerintah.

Bagi sebagian perhotelan tertentu, kebijakan larangan pegawai negeri sipil menggunakan hotel tidak menjadi masalah. Sementara bagi sebagian hotel lainnya, kebijakan itu akan menghambat tumbuh dan berkembangnya usaha mereka. Jika demikian adanya, industri amenitas yang merasa dirugikan dengan kebijakan pemerintah ini seharusnya memiliki rencana cadangan atau pun strategi lainnya jika menghadapi kondisi dan resiko di luar ekspetasi. Manajemen kritis harus diterapkan pihak pengelola hotel mengingat kompetisi akan semakin terbuka seiring dengan pakta integrasi yang akan dilakukan masyarakat Indonesia dengan masyarakat ASEAN di tahun 2015. Oleh karena itu, menyikapi kebijakan pemerintah yang terkesan tidak berpihak kepada industri amenitas, pengelola perhotelan harus melakukan terobosan. Lebih spesifik lagi adalah terobosan yang dilakukan dengan memperhatikan kebijakan lainnya yang berkembang saat ini, termasuk industri pariwisata di dalamnya.

\section{Upaya Investasi, Industri Pariwisata dan Industri Amenitas}

Untuk mengemas industri pariwisata lebih menarik, model pengembangan

\footnotetext{
${ }^{4}$ Antaranews.com, 7 November 2014
}

pariwisata tidak harus selalu ditunjukkan dengan pedoman yang bersifat konvensional semata. Investasi yang sejak era kepemimpinan Joko Widodo menjadi modal penggerak pembangunan bisa menjadi katalisator bagi pengembangan industri pariwisata, sehingga ketika atraksi pariwisata seperti atraksi seni budaya, atraksi obyekwisata natural dan atraksi obyek wisata artifisal ditawarkan, investasi bisa dikolaborasikan untuk meningkatkan pertumbuhan pariwisata. Apabila, pelaku usaha industri pariwisata, termasuk industri amenitas, melihat investasi sebagai usaha yang potensial dalam menarik jumlah kunjungan wisatawan, maka peluang untuk menumbuhkan dan mengembangkan usaha mereka setidaknya dapat diwujudkan.

Agar lebih mendukung kolaborasi antara pariwisata dengan investasi, pemberdayaan knowledge community harus menjadi faktor pendukung utama, selain pemerintah yang berfungsi sebagaipolicy maker yang merangsang berkembangnya inovasi dan kreativitas dalam industri pariwisata. Bahkan Yigitcanlar and Duh (2013) dalam studinya menemukan manfaat yang berarti dalam knowledge community yang mereka teliti di beberapa negara seperti Australia dan Singapura. Penguasaan lingkungan, sosial, maupun teknis pengendalian aktivitas yang bertumpu pada fasilitas penggunaan teknologi menjadi kunci keberhasilan sumber daya manusia yang terlibat di dalam industri pariwisata. Baik masyarakat maupun pemerintah merupakan key players yang menjalankan peran mereka masing - masing.

Industri amenitas pada dasarnya merupakan bagian dari knowledge community yang sudah terorganisir, sehingga sumber daya manusia yang dimiliki industri tersebut tentunya sudah tidak perlu diragukan lagi kemampuannya. Namun demkian, keluhan mereka yang terkait dengan kebijakan pemerintahyang melarang pegawai negeri sipil menggunakan hotel ketika melakukan aktivitas resmi pemerintahan sedikti 
menjadi bahan pertanyaan tentang kapasitas sumber daya manusia yang ada di industri amenitas. Kajian ini tidak melihat sampai sejauh mana kapasitas yang dimiliki oleh masing-masing sumber daya manusia yang ada di industri amenitas, sehingga menjadi keterbatasan studi ini yang tidak bisa kami sajikan secara menyeluruh. Namun, kami menyimpulkan bahwa sumber daya manusia yang ada di dalam industri amenitas masih perlu untuk terus belajar. Pembelajaran merupakan kunci penting untuk memecahkan permasalahan yang ada. Senge (1995), menurut tulisan yang dibuat oleh Sedarmayanti (2014: hal.89), menulis lima sikap disiplin agar pembelajaran di dalam sebuah organisasi dapat berjalan secara efektif. Kelima disiplin tersebut secara garis besar menekankan kepada pembelajaran secara sistemastis, pembelajaran mental, pembelajaran kepribadian, pembelajaran secara tim, dan pembelajaran berbagi pandangan. Kesemua disiplin tersebut merupakan pembekalan yang bertujuan untuk meningkatkan knowledge dan behaviour sumber daya manusia yang ada. Namun dari semua itu, kita akan bertanya-tanya kembali apakah semua itu sudah cukup memadai untuk meredam gejolak kekhawatiran industri amenitas terhadap kebijakan pemerintah.

Semua itu akan dikembalikan lagi kepada usaha yang dilakukan oleh masingmasing pengusaha dan pengelola hotel. Mereka memerlukan suatu usaha yang unik yang memungkikan dapat diterapkan dalam kondisi tertentu. Investasi dan pariwisata merupakan dua kutub yang berbeda, tetapi mereka bisa menghasilkan magnet yang sempurna. Jika dua kutub tersebut dapat dimanfaatkan oleh industri amenitas, maka peluang untuk pertumbuhan dapat terjadi. Industri pariwisata setiap tahunnya menunjukkan tren yang meningkat, meskipun peningkatannya tidak terlalu signifikan. Daya tarik pariwisata di kota Jakarta memang tidak sepopuler di kota-kota lainnya seperti Bali, tetapi kota Jakarta masih bisa bertahan dengan berbagai macam ragam aktivitas yang ditawarkan untuk mendorong peningkatan jumlah hunian tingkat hotel. Dalam studinya, Shahab (2001) menyimpulkan sebuah studi tentang identitas budaya lokal. Kesimpulannya memperlihatkan bahwa seni budaya Jakarta ternyata mampu menjadi inspirasi dan perhatian bagi masyarakat Indonesia seluruhnya. Ataudengan kata lain, seni budaya kota Jakarta mampu memberikan pengaruh bagi masyarakat Indonesia. Dengan menambahkan sentuhan kreativitas dan inovasi, seni budaya Jakarta bisa menjadi komoditas yang menarik yang dapat ditawarkan oleh industri amenitas guna meningkatkan kinerja industri pariwisata DKI Jakarta. Jika ini terus dilakukan, industri amenitas tidak akan terganggu dengan efisiensi fiskal yang dilakukan oleh pemerintah.

\section{SIMPULAN DAN SARAN}

\section{Simpulan}

Industri pariwisata merupakan salah satu industri yang bercirikan padat karya. Industri pariwisata memberikan kontribusi melalui berbagai aspek. Baik tenaga kerja maupun pajak yang diterima oleh pemerintah. Kebijakan larangan sebagaimana dilakukan oleh pemerintah tidak mengakibatkan turunnya jumlah tamu hotel di Jakarta. Apalagi pariwisata di DKI Jakarta lebih mengandalkan turis domestik yang berasal dari seluruh Indonesia. Kehadiran wisatawan domestik merupakan kekuatan bagi industri perhotelan di DKI Jakarta.

\section{Saran}

Mengingat industri pariwisata telah menjadi bagian penting dalam kegiatan perekonomian sekaligus sumber pendapatan pemerintah, pusat dan daerah, maka kebijakan pemerintah hendaknya lebih pada sisi sosial dan keamanan. Wisatawan domestik yang merupakan 
kekuatan dalam industri pariwisata lokal, perlu memperoleh suasana tenang, bersih, dan aman. Oleh karena itu penting untuk meningkatkan kesadaran warga Jakarta untuk lebih tertib dalam berbagai aspek. Termasuk dalam hal kebersihan, keamanan, lalu lintas, dan sebagainya. Tanpa adanya upaya pemerintah dan masyarakat melakukan peningkatan dari sisi-sisi tersebut maka sulit untuk meningkatkan jumlah kunjungan wisatawan domestik.

\section{DAFTAR PUSTAKA}

Buhalis, D. (2000). Marketing the Competitive Destination of the Future. Tourism Management, 21(1), 97-116

Farmita, A.R. PHRI Keberatan Larangan Pejabat Rapat di Hotel. Tempo.co., 8 November 2014. Dapat diakses melalui website: http://www.tempo.co/read/news/2 014/11/08/058620490/PHRIKeberatan-Larangan-PejabatRapat-di-Hotel. [diakses pada tanggal 2 Desember 2014]

Leiper, N. (1995). Tourism Management. Melbourine: RMIT Press

Maneenetr, T., Naipinit, A., \& Tran, T.H. (2014). Guidelines to Promote Local Community Participation in Developing Agrotourism: A Case Study of Ban Mor Village, Sam
Sung District, Khon Kaen Province, Thailand. Asian Social Science, 10(9), 178-186

Sedarmayanti. (2014). Membangun dan Mengembangkan Kebudayaan dan Industri Pariwisata. PT. Refika Aditama, Bandung. hal.89

Shahab, Y. (2001). Fashioning a National Cultural Heritage: The Revival of Lenong. Contemporary Theatre Review, 11(2), 13-23

Soepardi, H.S. PHRI Minta Larangan PNS Rapat di Hotel Ditinjau. Antaranews.com., 7 November 2014. Dapat diakses melalui website:http://www.antaranews.co m/berita/463055/phri-mintalarangan-pns-rapat-di-hotelditinjau. [diakses pada tanggal 2 Desember 2014]

Steinberg, F. (2007). Jakarta: Environmental Problems and Sustainability. Habitat International, 31(3-4), 354-365

Sunaryo, B. (2013). Kebijakan Pembangunan, Destinasi Pariwisata. Gava Media. Yogyakarta, hal.106

Yigitcanlar, T., and Dur, F. (2013). Making Space and Place for Knowledge Communities: Lessons for Australian Practice. Australasian Journal of Regional Studies, 19(1), 36-63 